\title{
The Impact of Subsidiary Autonomy on MNE Knowledge Transfer Resolving the Debate
}

\author{
Rabbiosi, Larissa
}

Document Version

Final published version

Publication date:

2008

\section{License \\ CC BY-NC-ND}

Citation for published version (APA):

Rabbiosi, L. (2008). The Impact of Subsidiary Autonomy on MNE Knowledge Transfer: Resolving the Debate.

Center for Strategic Management and Globalization. SMG Working Paper No. 16/2008

Link to publication in CBS Research Portal

\section{General rights}

Copyright and moral rights for the publications made accessible in the public portal are retained by the authors and/or other copyright owners and it is a condition of accessing publications that users recognise and abide by the legal requirements associated with these rights.

\section{Take down policy}

If you believe that this document breaches copyright please contact us (research.lib@cbs.dk) providing details, and we will remove access to the work immediately and investigate your claim. 
The Impact of Subsidiary Autonomy on MNE Knowledge Transfer: Resolving the Debate

\author{
Larissa Rabbiosi
}

SMG WP 16/2008

April 15, 2008 
SMG Working Paper No. 16/2008

April 15, 2008

ISBN: 978-87-91815-29-4

Center for Strategic Management and Globalization Copenhagen Business School

Porcelænshaven 24

2000 Frederiksberg

Denmark

www.cbs.dk/smg 


\title{
The Impact of Subsidiary Autonomy on MNE Knowledge Transfer: Resolving the Debate
}

\author{
Larissa Rabbiosi \\ Copenhagen Business School, Center for Strategic Management and Globalization, \\ Porcelaenshaven 24, DK2000, Frederiksberg, Denmark
}

\begin{abstract}
This paper explores theoretical and empirical ambiguities in the literature concerning the impact of foreign subsidiary autonomy on intra-MNE knowledge transfer. We argue that understanding the interdependences between subsidiary autonomy and the use of different communication systems - e.g. person-based and electronic-based communication systems - is crucial to putting forward new insights in the debate. Based on the recent literature on strategic management, we hypothesize that the two communication systems call for different degrees of subsidiary autonomy and vice versa. Using a data set consisting of 307 dyads between foreign subsidiaries and their parent companies, we find that two distinctive configurations positively affect the extent of knowledge transfer from foreign subsidiaries to their parent companies. The first is the combination of a high degree of subsidiary autonomy and the use of person-based mechanisms, and the second is the combination of low subsidiary autonomy and the use of electronic-based mechanisms.
\end{abstract}

Key words: reverse knowledge transfer, person-based mechanisms, electronic-based mechanisms, subsidiary autonomy, corporate-subsidiary decentralization

\section{Introduction}

Recent research argues that the creation and transfer of knowledge within and between firms is likely to significantly influence the value these firms can create and appropriate (Argote and Ingram 2000; Grant 1996). Accordingly, multinational enterprises (MNEs) might enjoy the important advantage of accessing country- and firm-specific knowledge available in multiple locations (Kogut and Zander 1993). As a result, strategic management research concerning the processes through which knowledge is transferred within MNEs and factors affecting such transfers has grown dramatically in the last decade (Bartlett and Ghoshal 1989; Björkman et al. 2004; Bresman et al. 1999; Chini 2004; Foss and Pedersen 
2002; Frost 1998; Gupta and Govindarajan 2000; Håkanson and Nobel 2000, 2001; Minbaeva et al. 2003; Mudambi 2002; Schulz 2001; Singh 2005; Szulanski 1996; Tsai 2001). In this context, several undertakings have emphasized the role of corporate-subsidiary decentralization (i.e. the extent of decisionmaking authority that is delegated to the general manager of a subsidiary by corporate superiors) in understanding the occurrence of knowledge transfer within the MNE. However, there seems to be little consensus on the effect of corporate-subsidiary decentralization (also called subsidiary autonomy) on knowledge transfer within MNEs. In fact, the literature has found everything from a positive to a negative effect over no effect at all (Birkinshaw et al. 2002; Foss and Pedersen 2002; Gammelgaard et al. 2004; Ghoshal et al. 1994; Lord and Ranft 2000; Tsai 2002).

The aim of this article is to provide new theoretical and empirical insights into the ambiguity in the literature concerning the impact of corporate-subsidiary decentralization on intra-MNE knowledge transfer. Specifically, we argue that one of the reasons why the previous findings are not unanimous in this regard is due to the fact that the research, as of today, does not relate subsidiary autonomy to the communication system utilized within the parent company-subsidiary relationship. The choice of the corporate-subsidiary communication system is one of the core dimensions of organizational structure and has been recognized to be very relevant in understanding knowledge transfer phenomena within MNEs (Almeida et al. 2002; Björkman et al. 2004; Chini 2004; Gupta and Govindarajan 2000; Hansen et al. 1999; Persaud 2005; Schulz 2001; Tsai 2002). The existing research has not, however, focused on the extent to which subsidiary autonomy and different communication mechanisms are interdependent in explaining intra-MNE knowledge transfer. Accordingly, in this paper we address this shortcoming by analyzing how subsidiary autonomy and the use of two different communication systems - person-based and electronic-based systems — depend on each other in affecting the extent of knowledge transfer to the parent company. In other words, our overall research question concerns whether knowledge transfer in MNEs increases when different degrees of autonomy granted to foreign subsidiaries are coupled with the use of distinctive communication systems applied within the parent company-subsidiary relationship. 
We limit our discussion to the extent of knowledge transfer from foreign subsidiaries to their parent companies (sometimes called "reverse knowledge transfer"). Accordingly, the unit of analysis is a dyad involving a focal foreign subsidiary and its parent company. Our primary concern in this article is the extent to which parent companies acquire and use knowledge from their overseas subsidiaries, with knowledge defined as "either expertise (e.g., skills and capabilities) or external market data of strategic value.” (Gupta and Govindarajan 1991, p. 773). Finally, within the broad spectrum of all possible types of electronically based mechanisms, we focus on communication technologies (e-mail, forum, listservs, etc.), knowledge repositories, and portals.

\section{Literature Review and Theory Development}

The corporate-subsidiary decentralization and the communication system are two very relevant organization structure dimensions in the international management literature (see, for example, Ambos and Schlegelmilch 2007; Asakawa 2001; Johnston and Menguc 2007; Nobel and Birkinshaw 1998; O'Donnell 2000; Taggart and Hood 1999) and these two variables have both been related to the occurrence of knowledge transfer within MNEs.

In research on multinational organizations, corporate-subsidiary decentralization has largely been operationalized at the dyadic level of the parent company's relationship with a specific subsidiary, by measuring the relative control exercised by the parent company on the subsidiary in making relevant decisions. In other words, it is a measure of subsidiary autonomy (for an exhaustive review of subsidiary autonomy in a MNE context, see, Egelhoff 1988; Paterson and Brock 2002; Young and Tavares 2004). Previous empirical studies disagree on the effect of subsidiary autonomy on knowledge transfer (Ghoshal et al. 1994). Foss and Pedersen (2002) and Tsai (2002) find a positive relationship between subsidiary autonomy and knowledge transfer. Other scholars' evidence suggests that corporate-subsidiary decentralization has a positive influence on inter-subsidiary knowledge flows but no effect (Ghoshal et al. 1994), or even negative impact on the transfer of knowledge from the subsidiaries to the parent companies (Gammelgaard et al. 2004). Lord and Ranft (2000) show a negative effect of corporate-subsidiary 
decentralization on knowledge transfer (cross-divisional), while Birkinshaw et al. (2002) do not find any impact of subsidiary autonomy on knowledge transfer.

Previous literature has highlighted that communication systems are fundamentally of two types: person-based and electronic-based (Haas and Hansen 2005; Hansen et al. 1999). The communication system is a response to the need to compete in a new international business environment that is increasingly complex and competitive. With each foreign subsidiary, the parent company will attempt to employ the communication approach that most effectively deals with the diversity of knowledge types and activities undertaken by the subsidiary. Accordingly, we might expect that a parent-subsidiary relationship will be managed emphasizing one approach more than the other in conformity with the type of the foreign subsidiary. A vast bulk of the literature has focused on the impact of formal and informal person-based relationships on knowledge transfer (Björkman et al. 2004; Gupta and Govindarajan 2000; Schulz 2001; Singh 2005; Tsai 2002). However, empirical consensus also exists on the role played by mechanisms based on the electronic media in the international transfer of knowledge (Almeida et al. 2003; Almeida et al. 2002; Andersen and Foss 2005). Specifically, electronic communication systems, from telephones and electronic mail to more sophisticated systems, such as electronic conferencing, discussion databases, and group decision support software, enable communication among managers of different units and the sharing of different types of documents (DeSanctis and Fulk 1999; Niederman 2005; Persaud 2005; Sambharya et al. 2005). Nevertheless, there is an incomplete understanding of the potentially dissimilar roles of intra-MNE knowledge transfer through person-based mechanisms and mechanisms including the use of electronic media.

Although each of the earlier studies has advanced our understanding significantly, they have remained largely disconnected. We expect that different degrees of subsidiary autonomy call for more emphasis on the use of one communication system than the other. In particular, we consider two distinctive configurations that we conjecture will positively impact the extent of reverse knowledge transfer. On the one hand, the combination of a high degree of subsidiary autonomy and a greater use of person-based mechanisms, and, on the other hand, the combination of a low degree of subsidiary 
autonomy and a greater use of electronic-based mechanisms. However, it should be noted that we are not arguing that an exclusive use of one communication system is beneficial or even desirable. In this article, we are neither stressing nor excluding the existence of synergic effects between person-based and electronic-based communication systems. Instead, what we argue is that, although both mechanisms may co-exist in the parent-subsidiary relationship, in order to increase the extent of reverse knowledge transfer, the emphasis on each mechanism should differ according to the managerial choice made on the degree of autonomy granted to the foreign subsidiary. In the following, we will look at each of the two configurations in turn.

\section{Person-based Communication, Subsidiary Autonomy, and Knowledge Transfer}

A greater degree of autonomy is often considered positively related with subsidiaries' knowledge creation and development (Ghoshal and Nohria 1989; Gupta and Govindarajan 1991; Nohria and Ghoshal 1994; Persaud 2005), based on the idea that independent subsidiaries have strategic mandates (Birkinshaw et al. 1998) that favor local responsiveness (Bartlett and Ghoshal 1989) and knowledge development by tapping into local knowledge bases (Andersson et al. 2002; Cantwell 1995). Although opposite results have also been found (Brockhoff and Schmaul 1996; Frost et al. 2002), management scholars tend to agree on the idea that the autonomy solution enhances the subsidiary's ability to learn from the local system of innovation and allows the MNE to benefit from new knowledge developed by independent subsidiaries (Cantwell and Mudambi 2005; Foss and Pedersen 2002; Nobel and Birkinshaw 1998; Taggart and Hood 1999).

Further, when a subsidiary's ability to create and develop new knowledge increases, it is obviously more likely that the subsidiary owns valuable knowledge for the parent company and for the MNE as a whole (Cantwell and Mudambi 2005). Nevertheless, the subsidiaries' ability to create and develop new knowledge may have a negative impact on reverse knowledge transfer. First, the creation and development of new knowledge by foreign subsidiaries might be based on intensive information exchange with local organizations that leads to more context specific and complex knowledge (Andersson et al. 
2002). Under these conditions, it will be more difficult to apply the subsidiary knowledge in the parent company. Second, when subsidiaries are exposed to major internal competition and when knowledge is a crucial source of their competitive advantage (Birkinshaw and Hood 1998), subsidiaries may choose to make the knowledge they control excludable and they will be prevented from engaging in reverse knowledge transfer (Foss and Pedersen 2002; Gupta and Govindarajan 2000). Hence, when a too high level of autonomy is granted to the subsidiary, the connections and dependency between the parent company and the subsidiary will decrease, and reciprocal trust can be reduced, thus diminishing the transfer of knowledge to the other units of the MNE (Forsgren et al. 2000). This is in line with previous findings showing a negative impact of subsidiary autonomy on knowledge transfer (Gammelgaard et al. 2004; Lord and Ranft 2000).

We argue that overcoming these negative circumstances is possible through the increased use of person-based mechanisms. In other words, we expect to observe a positive impact on reverse knowledge transfer when a high degree of subsidiary autonomy matches a greater use of person-based mechanisms within the parent-subsidiary relationship. Our prediction originates in the results of the previous management literature.

First, it is possible to observe that a motivation mechanism is at work. In fact, it has been observed that a higher level of subsidiary autonomy will increase the motivation and the initiatives that a unit can take in intra-group knowledge exchange (Tsai 2002). Recent studies argue that employees' intrinsic motivation has a positive effect on knowledge transfer (Bock et al. 2005; Cabrera et al. 2006; Mudambi et al. 2007; Osterloh and Frey 2000), while the extrinsic motivational disposition of a source unit to transfer its knowledge does not affect intra-MNE knowledge transfer (Gupta and Govindarajan 2000). Furthermore, intrinsic motivation fosters participation and personal relationships among employees because their perceived self-determination is raised and psychological contracts are established: the socalled "team spirit" is enabled (Osterloh and Frey 2000). Intrinsic motivation is closely linked to more exploratory thinking and greater intellectual challenge (Amabile 1997). Therefore, in organizations that adopt person-based mechanisms more strongly, it is more likely that employees exploit their analytic and 
creative skills by working on unique business problems, and they share complex and tacit knowledge (Hansen et al. 1999; Osterloh and Frey 2000). Accordingly, a high corporate-subsidiary decentralization that favors individuals' intrinsic motivation (Mudambi et al. 2007) will match the transfer of complex knowledge from subsidiaries to parent companies through person-based mechanisms.

Second, "once organizations are viewed as institutions for integrating knowledge, a major part of which is tacit and can be exercised by those who possess it, then hierarchical coordination fails" (Grant 1996, p. 118). At the same time, organizations that rely on knowledge that is rich and subtle, i.e. complex, are more likely to adopt the 'personalization' approach (Hansen et al. 1999) and, accordingly, to base their communication system predominantly on person-based mechanisms (Gupta and Govindarajan 2000; Haas and Hansen 2005; Pedersen et al. 2003; Persaud 2005). In this context - using patent citation data - Singh (2005) finds a greater probability of knowledge flows within a firm when inventors have close interpersonal ties. Moreover, recent research on search for innovation emphasizes that the mobility of individuals is not only an opportunity to transfer own expertise, but also to facilitate the interpretation of this knowledge in a new context (Rosenkopf and Almeida 2003). Thus, from a cognitive perspective, when subsidiary knowledge becomes more complex and tacit, the use of richer information transmission channels, i.e. person-based mechanisms, will be preferred due to their better capacity of transferring complex and tacit knowledge (Daft and Lengel 1986; Gupta and Govindarajan 1991).

Finally, the socialization models of organizational control discuss the use of training, teamwork and other person-based mechanisms to disseminate the mission, goals, values and cultures of organizations to workers to transcend their varied interests and align their goals with the values of the organization (Johnson and Medcof 2007). On the one hand, the literature seems to disagree on the ultimate effect of socialization on foreign subsidiary ability of augmenting its capabilities. For instance, Ambos and Reitsperger (2004) find a negative relationship between high socialization and the technical success of centers of excellence abroad. However, when other control modes are taken into account, the results show that higher levels of socialization combined with lower levels of formalization and centralization positively affect subsidiary initiatives to develop and create new knowledge (Nobel and Birkinshaw 
1998). On the other hand, the impact of socialization on knowledge transfer appears more univocal: shared values and identity facilitate meaningful communication that is essential in knowledge transfers (Nahapiet and Ghoshal 1998). Nevertheless, Tsai (2002) suggests that the effectiveness of coordination mechanisms (e.g. centralization and socialization) on knowledge transfer depends upon the conditions of competition among organizational units. Specifically, he argues that, on the one hand, competitive units will react negatively (i.e. transfer less knowledge) toward tight control by the headquarter, as they may suspect that the headquarter will sacrifice some units' interests and make decisions in favor of other units. On the other hand, more socialization interactions will positively affect knowledge transfer among competing organizational units because of their strong incentive to understand what the other competitor units are doing. The power-dependence structure within the MNE is also reflected in the autonomy-control tension (Asakawa 1996). Specifically, it has been observed that foreign activities need greater autonomy to increase their connections with the external research community thereby increasing their own knowledge. However, this may induce a lack of balance between internal and external linkages and generate autonomy-control tension with the parent company as well as with the other units (Asakawa 2001). In this context, higher levels of socialization will stimulate the formation of convergent interests, the sharing of beliefs, common values and norms between managers of different units (Tsai and Ghoshal 1998), and, therefore, the parent-subsidiary tension will be reduced (Jaeger and Baliga 1985). Accordingly, the extensive use of a person-based communication (more than electronic-based communication) in the parent company-subsidiary relationship will enhance trust and a shared vision within the MNE, also under conditions of internal competition. Thus, also from a socialization/trust perspective, the combination of subsidiary autonomy and a higher use of person-based mechanisms will be positively related to the extent of reverse knowledge transfer.

Based on the above considerations, the following hypothesis is formulated:

HYPOTHESIS 1. A higher degree of subsidiary autonomy applied together with a higher use of personbased communication increases the extent of reverse knowledge transfer. 


\section{Electronic-based Communication, Subsidiary Autonomy, and Knowledge Transfer}

Information systems are designed to support and augment organizational knowledge management and need to complement and enhance the communication ability of the firm (Alavi and Leidner 2001). While not all knowledge management strategies - in particular person-based strategies - involve a wide implementation of information and communication technology (ICT), many knowledge management initiatives rely on ICT as an important enabler (Haas and Hansen 2005). In the introduction, we clarified that we focus on a specific group of electronic-based mechanisms; specifically, communication technologies (e-mail, forum, chat, etc.), knowledge repositories, and portals, i.e. 'exploitation mechanisms' (Kane and Alavi 2007). In the following, we will use the terms "electronic-based mechanisms" and "exploitation mechanisms" as synonyms.

As mentioned above, empirical consensus exists on the role played by electronic-based mechanisms in intra-MNE knowledge transfer. In particular, electronic tools are effective for transferring standard data and well understood messages and information, while their limitations are revealed when less codified knowledge has to be transferred (Daft and Lengel 1986; Pedersen et al. 2003). Indeed, the adoption of exploitation mechanisms requires firms to develop 'knowledge objects' (Hansen et al. 1999; Zack 1999), that is, knowledge that can be viewed as a thing to be stored and manipulated. Such knowledge is collected mostly in databases, reports, or handbooks through a "people-to-documents" process, and it can be accessed and used relatively easily by anyone in the company (among others see, Hansen et al. 1999; Zollo and Winter 2002). Accordingly, the effective transfer of tacit knowledge through electronic-based mechanisms will also be possible in many cases, but only after the application of a specific codification strategy that involves the transformation of tacit knowledge into explicit knowledge (Schulz and Jobe 2001). Therefore, the use of multiple electronic-based mechanisms dispersed across distance, time, and cultures, can lead to the spreading of diverse and incompatible codification/people-todocument processes within the MNE (Rao et al. 2007), giving rise to no or inefficient reverse knowledge transfer. In fact, in this case, we would observe increasing costs of transferring knowledge within the 
MNE due to differences in coding methods, languages, understanding of phenomena and context, etc., and lower compatibility of internet instruments across borders.

We argue, however, that overcoming these inefficiencies is possible through the reduction of subsidiary autonomy. More precisely, we expect to observe a positive impact on reverse knowledge transfer when a low degree of subsidiary autonomy is combined with a greater use of electronic-based mechanisms within the parent-subsidiary relationship. The argument runs as follows. Common standards, languages, procedures, and routines, and global infrastructures will play a crucial role in MNEs that rely more extensively on electronic-based communication and, therefore, need to share codification strategies among the different units. Only if standardization, communalities, and compatible ICT systems are well spread and maintained over some time horizon among the units, will MNEs be able to achieve efficient knowledge transfer when using electronic-based communication. The management information systems literature has suggested that a decentralized MNE will be more likely to pursue independent ICT operations in each subsidiary (Jarvenpaa and Ives 1993). A high level of corporate standards may, moreover, be perceived as intrusive from local managers with a high degree of autonomy in decision making (Karimi and Konsynski 1991). On the other hand, in centrally coordinated MNEs, ICT systems are also usually globally centralized (King and Sethi 1999). Centralized electronic databases are effective for collecting rationalized knowledge (Weiss 1998). In fact, codification strategies involve considerable costs of creating and maintaining repositories of organizational knowledge (Hansen et al. 1999; Schulz and Jobe 2001). To make sure that the codification process works efficiently, organizations have to invest a lot to create an integrate electronic repository, have comparable formats, and design a customized and common taxonomy (Weiss et al. 2004). An advantage of centralization is that it allows MNEs to avoid having multiple divisions or groups within the MNE create their own unintegrated intranet portals or data warehouses and the like. When information architectures vary across systems as well as formats, employees are unable to browse contents easily and efficiently. A central player can ensure consistency of formats and standards can be institutionalized more broadly across the organization (Karimi and 
Konsynski 1991). Common attributes, coding schemes, and values across databases are necessary for economizing data sharing (Goodhue et al. 1988).

Much recent literature has shown that exploitation mechanisms reduce knowledge heterogeneity and promote exploitation learning (Kane and Alavi 2007), such as incremental learning focused on refinement, and reuse of existing knowledge (March 1991). It has also been observed that organizations that experience minor environmental turbulence will benefit from exploitation mechanisms (Kane and Alavi 2007), while organizations might abstain from codifying their knowledge if the costs of the process exceed the benefits. Accordingly, emphasizing greater use of electronic-based mechanisms - within the parent-subsidiary relationship - combined with a highly decentralized and competence-creating subsidiary (Cantwell and Mudambi 2005), which generally faces complex knowledge and more a turbulent environment, is likely to be inefficient. On the other hand, the transfer of knowledge from subsidiaries to parent companies through electronic-based mechanisms, will be greater under conditions of low subsidiary autonomy where subsidiaries are expected to face environments of relatively low complexity (Ghoshal and Nohria 1989) and where their knowledge is mainly explicit or codifiable in a cost-efficient manner (Schulz and Jobe 2001).

Based on these arguments, we suggest the following hypothesis:

HYPOTHESIS 2. A lower degree of subsidiary autonomy applied together with a higher use of electronicbased communication increases the extent of reverse knowledge transfer.

\section{Methodology}

\section{Sample and Data Collection}

As our study concerns the impact of the organizational structure on the extent of knowledge transfer from a focal foreign subsidiary to its parent company, we consider the dyad of a focal foreign subsidiary and its parent company as the unit of analysis. Using this dyadic approach, we created a dataset of 307 observations. 
Our sample selection was guided by the following criteria. First, we generated the sample frame from the Reprint database (Mariotti and Mutinelli 2005), which contains census data on the foreign activities of the Italian firms as of the beginning of 2004. Second, we limited the sample frame to the population of all Italian MNEs with more than 50 employees, operating in manufacturing industries, and with at least one majority-owned subsidiary located in advanced countries and involved in "primary upstream activities" such as R\&D and manufacturing. The final sample frame consists of a total of 358 Italian MNEs, out of which 84 were studied through on-site face-to-face structured interviews with the parent company's top managers (response rate of about 24 percent). Five of these MNEs also served as sites for the pre-testing and refinement of the questionnaire.

Data collection took place from December 2004 to July 2005 and involved six researchers. All parent companies' top managers were contacted by phone and asked for a face-to-face interview. At the same time a personalized letter with a description of the project and assurances regarding the confidentiality of collected data was sent to them. The interviews ranged from one to three hours in length; however, for most of the parent companies with more then five subsidiaries $(20 \%$ of the sample), we were able to obtain longer interviews, sometimes based on two-day meetings. For each of the 84 MNEs we collected data regarding the dyadic relationships of the parent company with each of its majority-owned foreign subsidiaries involved in manufacturing or R\&D activities.

\section{Measures}

\section{Reverse Knowledge Transfer}

Following Gupta and Govindarajan (1991), we define knowledge flows as the transfer of either skills and capabilities (i.e. expertise) or external market information of strategic value, such as globally relevant information about key customers, competitors, or suppliers, from the foreign subsidiary to its parent company. Using open questions, informants were first asked to provide descriptions on the subsidiary's expertise regarding products, technologies, and primary activities (Schulz 2001). Next, structured questions were posed, focusing on whether the identified subsidiary's knowledge pertaining to the above 
three domains was transferred to, and used by, the parent company. Examples of these questions are: has the subsidiary's technology that you described been transferred to and used by the parent company? Have the specific subsidiary's competences that you described been transferred to and used by the parent company? Finally, the respondents were asked to indicate the intensity of the knowledge transfer from the subsidiary to the parent company ("null', 0; "low," 1; "medium," 2; "high," 3). Based on this last answer, we define the dependent variable reverse knowledge transfer, ranging from 0 (no transfer at all), to 3 (high transfer). Therefore, transfers were assessed from the receiving unit's perspective, i.e. the parent company. In line with Lord and Ranft (2000, p. 582), "this was done primarily because to try to measure knowledge transfer from the sender's perspective is inherently problematic - e.g., knowledge that is 'sent' is not always 'received' (Szulanski 1996).”

\section{Subsidiary Autonomy}

The measure of corporate-subsidiary decentralization is essentially based on questions originally developed by Ghoshal and Nohria (1989). Specifically, we know at which MNE level each of the following four firm's strategic decisions are taken: (i) definition of R\&D projects, planning, resources, etc.; (ii) introduction of new technologies; (iii) changes in products/services; and (iv) hiring and firing of the subsidiary management. The following scale was used: (1) 'the parent company decides alone'; (2) 'the parent company decides but considers subsidiary inputs'; (3) 'both parent company and subsidiary have roughly equal influence on decisions'; (4) 'the subsidiary decides, but considers parent company suggestions'; and (5) 'the subsidiary decides alone' (Ghoshal et al. 1994; Ghoshal and Nohria 1989). The final measure of subsidiary autonomy is the average of responses to the four items (Cronbach's alpha = $0.74)$.

\section{Person and Electronic Based Communication Systems}

Inter-unit trips and visits, international committees, teams, task forces, and training involving participants from multiple units have been found to facilitate MNE integration and favor knowledge transfer (Björkman et al. 2004; Bresman et al. 1999; Chini 2004; Ghoshal et al. 1994; Gupta and Govindarajan 2000; Håkanson and Nobel 2001; Hansen 1999; Nobel and Birkinshaw 1998; Schulz 2001; Tsai 2001; 
2002). To capture parent-subsidiary communication based on personal ties we focus on teamwork involving people from both the foreign subsidiary and the parent company, and the temporary (short-term) transfer of managers and/or scientific and technical staff (researchers, engineers, etc.) within the parentsubsidiary dyad. As regards short-term transfer, the respondents were asked to consider the movement of people other than people visiting for only one or a few days or expatriates. Respondents were asked to assess the intensity of the use of the three person-based mechanisms on a 7-point Likert scale, from 'used rarely' to 'used very often'. The final measure of person-based is the average of responses to the three items (Cronbach alpha $=0.72)$.

We capture electronic based communication by the intensity of the use of internet instruments, such as forums, newsletters, e-mails, instant messages, etc., and the sharing of documents like handbooks, blueprints, databases, in the parent-subsidiary relationship (Pedersen et al. 2003; Persaud 2005). Based on a 7-point Likert scale, from 'used rarely' to 'used very often', the final measure of electronic-based is the average of responses to the two items (Cronbach's alpha $=0.60){ }^{1}$

\section{Interaction Effects}

To capture the combined effect of using a specific communication system under different degrees of subsidiary autonomy, we follow previous works (Birkinshaw et al. 2002; Schoonhoven 1981) in constructing interaction terms between both the two communication systems and the decision making variable. Specifically, we add to the model the following variables: person-based $\times$ subsidiary autonomy and electronic-based $\times$ subsidiary autonomy. In order to support our hypotheses, we expect a positive and a negative effect on the extent of reverse knowledge transfer, respectively.

\section{Control Variables}

\footnotetext{
${ }^{1}$ Although the value of 0.7 is often used as a guide for Cronbach's Alpha, Nunnally (1967) recommends a value equal to or greater than 0.60 as the minimum for research purposes. While our results concerning electronic-based communication have to be taken with the necessary caution, we contend that this does not undermine them since key variables with similar values of Cronbach's Alpha have been used successfully in previous knowledge-transferrelated research (among others, see Schulz 2001; Szulanski 1996).
} 
- Subsidiary mandate. Previous literature has linked our organizational structure dimensions with the strategic subsidiary mandate (Ambos and Schlegelmilch 2007; Bartlett and Ghoshal 1989; Ghoshal and Nohria 1989; Gupta and Govindarajan 1991; Nobel and Birkinshaw 1998). There is a recent but now well established literature on the diversity of subsidiary roles within an MNE. Some of the subsidiaries within the MNE network may crucially depend on the competence of their parent companies, so that their role is competence-exploiting (Cantwell and Mudambi 2005), either as a local implementer (Gupta and Govindarajan 1991), or as an assembler (Cantwell 1987); others take on a more creative function (Pearce 1999) as integrated players (Gupta and Govindarajan 1991) or as centers of excellence (Holm and Pedersen 2000).

Studies have utilized a series of different approaches to operationalized subsidiary typologies. We adopt the implementation of this variable from Ghoshal (1986), distinguishing among 'implementer subsidiary', 'contributor subsidiary', and 'innovator subsidiary'. We also follow Nobel and Birkinshaw (1998) and Ambos and Schlegelmilch (2007) and apply a rather simple heuristic based on the nature of the subsidiary activities. The respondents were asked to indicate whether the focal foreign subsidiary was devoted to 'capability-augmenting' or 'capability-exploiting' activities. The former group's activities are undertaken to create new products and/or new technologies whereas the latter group focuses on activities directed towards significant and/or marginal product/process improvements. Those subsidiaries that are neither capability-augmenting nor capability-exploiting are called Implementers, those that are only capability-exploiting are Contributors, while those that are capability-augmenting are labeled Innovators. - Entry mode. Although acquisitions and joint ventures have traditionally been seen as a common way for the MNE to access local competencies and skills (Bresman et al. 1999; Kogut and Zander 1993; Lane et al. 2001; Simonin 1999), empirical studies also found that the incidence of technology transfer from subsidiaries to parent companies is higher for greenfield subsidiaries than for acquisitions (Frost 1998; Zhou 2002). Therefore, in order to capture the effects of the entry mode on reverse knowledge transfer, we add to the model the dummy variable greenfield. 
- Cultural distance. Cultural distance is measured utilizing Kogut and Singh's (1988) cultural distance index (among the others that have previously adopted this measure, see for instance Ambos et al. 2006; Håkanson and Nobel 2001).

- Industry. As foreign subsidiaries operating in different industries face different technological opportunities to enhance knowledge creation and development, we control for the industry. We define the dummy high-tech that equals one if the subsidiary operates either in science-based or specialized suppliers sectors (Pavitt 1984).

- Parent company absorptive capacity. This variable is based on parent companies' balance sheet data in 2004, and it aims to control for the existence of prior knowledge in the parent company. This knowledge is expected to facilitate the understanding of possible incoming knowledge from the subsidiary. The variable is defined as the ratio of parent intangible assets (in millions of Euros) and the number of employees of the parent company.

\section{Testing for Response Bias}

To assess non-response bias, we tested whether responding MNEs differ from non-responding MNEs with respect to size (class of number of employees) and sector. The tests indicate that low-tech sectors are underrepresented $(\mathrm{p}<0.001)$ in our sample (see Table 1). Accordingly, the generalization of our results concerning low-tech industries must be taken with the necessary caution. However, it should be noted that previous findings suggest that firms in low-tech sectors have a much lower tendency to engage in reverse knowledge transfer from their subsidiaries, since foreign technology is generally obtained from outside the firm's boundaries (Brusoni et al. 2001). This is in line with the information put together during the data collection process: most of the MNEs investing abroad in low-tech sectors declared that they do not consider the possibility to transfer back knowledge from their subsidiaries an important issue. That has curbed their interest in participating in the project.

\section{- INSERT TABLE 1 ABOUT HERE -}

The use of perceptual measures introduces the risk of common method bias. To assess common method bias in our sample, we performed the Harman's single-factor test (Harman 1967; Podsakoff and 
Organ 1986) on items included in our econometric model. The factor analysis reveals six factors with eigenvalues greater than one, the first of which (eigenvalue $=3.17$ ) explains $19.82 \%$ of the variance. This result indicates that common method bias is not a serious problem.

To rule out possible one-respondent bias, we performed validity response tests on our dependent and independent variables based on perceptual data. In fact, for 62 dyads we were able to collect relevant information from both the parent company's manager and the subsidiaries' top manager. Therefore, we present the Kruskal-Wallis equality of populations rank test that tests the hypothesis that two (or more) samples are from the same population (Brett et al. 1995; Downey et al. 1975). In general, the validity tests confirm that the responses from managers at the parent company and at the subsidiary regarding our dependent and independent variables are not significantly different (see Table 2). The only exception concerns the items "temporary transfer of managers" and "temporary transfer of professionals". Specifically, the parent companies perceive a greater number of personnel transfers with their subsidiaries than the foreign subsidiaries perceive. However, this difference is to be expected. Although personnel transfers may be one-way or two-way (from the parent company to the subsidiary and vice-versa), we know from the interviews that it is mostly a uni-directional movement (from the parent to the subsidiary). Also taking into account that the diffusion of this work practice in the MNE is usually encouraged and formalized by the parent company, it is not surprising that the foreign subsidiaries report using smaller numbers of personnel transfers than their parent companies.

- INSERT TABLE 2 ABOUT HERE -

\section{Results and Discussion}

The summary of the descriptive statistics and correlations for all variables in this study are reported in Table 3. No variables exhibit distribution or correlation problems. Given the ordinal nature of our dependent variable, we estimate ordered probit models. Results from the econometric estimations are reported in Table 4, while the relevant marginal effects are reported in Table 5. We standardized the independent variables by subtracting the mean and dividing by the standard deviation, in order to avoid 
high correlation between these variables and their interaction terms (Neter et al. 1990). The dyadic approach raises an issue of possible non-independence among the observations (Greene 2000). Therefore, using the Stata's cluster option we obtain a robust variance estimate that adjusts for within-cluster correlation (Froot 1989; Williams 2000)). In this way we are able to control for the fact that observations (i.e., dyads) belonging to the same MNE are possibly not independent. Three models are presented in Table 4. In Model 1, we enter only the control variables, in Model 2 we add the independent variables, and in Model 3 we insert the interaction terms for testing our hypotheses.

\section{- INSERT TABLE 3 ABOUT HERE -}

With respect to the control variables, it is worth observing that in line with the theory, our estimations reveal that contributor and innovator subsidiaries are more likely to transfer knowledge to their parent companies than implementer subsidiaries (i.e. the benchmark).

Turning to the independent variables, our results show that both communication systems are positively related to reverse knowledge transfer. In Model 2, the variable person-based shows a positive and significant coefficient $(\mathrm{p}<0.01)$ indicating that the circulation of staff internationally generates a greater degree of reverse knowledge transfer. An extensive use of face-to-face mechanisms maximizes the level of interaction with employees of the parent and the subsidiary, offering the greatest opportunity to transfer knowledge through the grafting of individuals with special expertise. An extensive use of exploitation mechanisms also enhances reverse knowledge transfer, since the coefficient of electronicbased mechanisms is positive and significant at $\mathrm{p}<0.1$. When we add the interaction terms to the model (Model 3), it can be observed that the coefficients of person-based and electronic-based continue to be positive and significant $(\mathrm{p}<0.01$ and $\mathrm{p}<0.05$, respectively). These results are in line with the previous literature on knowledge transfer that suggests both types of communication systems as effective channels for transferring knowledge. However, based on the idea that the right combination of interdependent dimensions should lead to superior performance, we expect that a greater emphasis on one of the two possible communication systems will be associated with a higher degree of reverse knowledge transfer under different subsidiary autonomy conditions. This interdependence between corporate-subsidiary 
decentralization and communication systems is also apparent when the coefficient for subsidiary autonomy is examined; it is not significant in Model 2 but significant in Model 3, where we control for different communication systems that we expect to interact with the degree of subsidiary autonomy.

\section{- INSERT TABLES 4 AND 5 ABOUT HERE -}

With respect to our hypotheses, the coefficients of the interaction terms person-based $\times$ subsidiary autonomy and electronic-based $\times$ subsidiary autonomy are significant and have the right sign, positive and negative, respectively. These findings are well in line with our theoretical predictions, thus supporting Hypotheses 1 and 2. Our results confirm that the interdependence among organizational structure dimensions, specifically subsidiary autonomy and communication systems, should be considered an important contingency affecting effective reverse knowledge transfer. Based on the results of the recent research in strategic management, we expect - and our estimations confirm - that increasing levels of subsidiary autonomy with an increased use of person-based communication will lead to higher levels of reverse knowledge transfer, while increased use of electronic-based media should be coupled with decreasing levels of subsidiary autonomy and should hence lead to higher levels of reverse knowledge transfer.

The negative effect of the interaction of electronic mechanisms with subsidiary autonomy can be said to give support to the information processing theory advanced by Egelhoff (1988), since the theory suggests that "information processing" works better when centralization dominates, and given that electronic media may be considered carriers of "information" in the Egelhoff sense of the word. Centralization helps to reduce costs that include redundancies, incompatibility, lack of common understanding and standards, whose existence is expected to decrease the effectiveness of the use of the exploitation mechanisms (i.e. communication technologies such as e-mail, forum, listservs, etc., knowledge repositories, and portals). In addition, when subsidiary autonomy increases differences among parent and subsidiary 'knowledge structures', which may include knowledge domain, terminology, interpretation of phenomena and social context, are expected to increase, giving rise to misunderstandings 
between senders and receivers, limiting codification strategies and the electronic media impact on reverse knowledge transfer.

Considering rich communication media, we know - as the literature suggests - that they are costly to maintain (Daft and Lengel 1986; Pedersen et al. 2003) due to travel costs, availability of time, and differences in cultures and language; therefore, their extensive use should be justified. Accordingly, a contingency perspective is warranted. That is to say, effective management of knowledge transfer from high autonomous subsidiaries - expected to be more innovative and to own complex and context specific knowledge (Cantwell and Mudambi 2005; Gupta and Govindarajan 1991) - requires the use of richer communication mechanisms (Daft and Lengel 1986), and parent companies will be willing "to pay" because of the expected positive influence on the costs and benefit trade-off in such transfer processes. Whereas managers will face several difficulties in transferring context and tacit knowledge across countries through exploiting mechanisms (Persaud 2005), significant investments in ICTs for supporting electronic-based communication may be not justified if the people-to-documents process cannot be pursued in an economic way or too much knowledge is lost during the transfer.

\section{Additional Analysis}

It is crucial to clarify that in non-linear models, such as ordered probit models, the impact of the interaction term on the dependent variable is "a function of not only the coefficient for the interaction, but also the coefficients for each interacted variables and the values of all the variables." (Hoetker 2007, p. 336). More unexpectedly, the sign of the effect of the interaction may be different for different observations, and the statistical significance cannot be determined from the z-statistic reported in the regression output (Norton et al. 2004). To date, unfortunately, no procedure dealing with interaction terms for ordered probit models has been developed. However, Ai and Norton (2003) have proposed a procedure that computes correct magnitudes and standard errors of interaction effects in logit and probit models (this procedure has been implemented in STATA through the inteff module). Accordingly, in order to deal with this complication - unreliability of interaction terms in non-linear models - we opted for a conservative choice, running a probit estimation of Model 3, applying the Ai and Norton's (2003) procedure (see also, 
Norton et al. 2004). We transformed our dependent variable into a binary variable by collapsing all the observations with reverse knowledge transfer equal to 1,2 , or 3 to the value of 1 . We are aware that this operation removes a great deal of the variance in our model, but we also think that this conservative choice is crucial in order to provide an appropriate and complete interpretation of our findings.

Based on results from Model 6 (Table 6), the graphs in Figure 1 compare the interaction effect calculated by the conventional linear method with the interaction effect calculated by the method suggested by Norton et al. (2004) against predicted probabilities of reverse knowledge transfer equal to one. The graphs in Figure 2 plot the statistical significance of the interaction effect against predicted probabilities of reverse knowledge transfer equal to one.

\section{- INSERT TABLE 6 ABOUT HERE -}

Considering person-based communication, Figure 1(a) illustrates that the strongest interaction effect occurs at medium predicted levels of probability of reverse knowledge transfer (approximately between 0.2 and 0.6), whereas the effect is less pronounced for low and high levels of predicted probability of reverse knowledge transfer. In Figure 1(b), a similar path is observable for electronic-based mechanisms where the strongest interaction effect occurs approximately between 0.2 and 0.8 of the predicted levels of probability of reverse knowledge transfer. Figure 2(a) illustrates that the interaction effect of subsidiary autonomy and person-based mechanisms is positive and significant in the majority of cases within the 0.2-0.6 interval of the predicted probability $(80.7 \%$ of the observations are significant at the two-tailed ten percent level), while Figure 2(b) shows that the interaction term of subsidiary autonomy and electronic-based communication is negative, but also significant in the majority of cases within the 0.2-0.8 interval of the predicted probability $(83.8 \%$ of the observations are significant at the two-tailed ten percent level). These results are in line with the findings from the ordered probit estimation and they offer evidence of the positive role on reverse knowledge transfer played by the use of person-based communication under conditions of high subsidiary autonomy. Likewise, they provide support for the result that under conditions of low subsidiary autonomy, the emphasis should be on electronic-based communication. 


\section{- INSERT FIGURES 1 AND 2 ABOUT HERE -}

\section{Conclusion}

This work has sought to make a contribution to the ongoing debate of the impact of subsidiary autonomy on intra-MNE knowledge transfer. The key contribution to the strategic management literature was to identify and examine the implications of the interaction effects between the corporate-subsidiary decentralization and the use of different communication systems, i.e. person-based and electronic-based systems, as an important feature of the intra-MNE knowledge transfer. While the relevance of both subsidiary autonomy and communication systems in knowledge transfer processes within MNEs has been acknowledged before, they have typically been treated as independent dimensions. This has led to conflicting results of the impact of subsidiary autonomy on knowledge transfer. In this study we have argued and empirically substantiated that to resolve the ambiguity in the literature regarding the effect of the subsidiary autonomy on knowledge transfer it is crucial to consider which communication system is emphasized within the parent-subsidiary relationship. Specifically, we considered two distinctive configurations of interdependence: the combination of a high degree of subsidiary autonomy and the use of person-based mechanisms, and the combination of a low degree of subsidiary autonomy and the use of electronic-based mechanisms.

This study also offers potentially important implications for parent companies' managers. In fact, not all firms are equally capable of transferring knowledge inside the MNE, in particular, the managerial choice of how to set the organizational structure variables is one that most directly reflects how to facilitate or inhibit knowledge transfer. Thus, although all the potential obstacles that parent companies' managers may face in pursuing knowledge transfer within the multinational network cannot be addressed, our results suggest actions and provide guidance for managers. By identifying the combination of the corporate-subsidiary decentralization and communication systems that enhances the extent of reverse knowledge transfer, the primary practical implication is that parent companies can employ organizational structure dimensions as a strategic choice for affecting effective reverse knowledge transfer. In line with previous findings, the empirical analyses showed that both person-based and electronic-based 
communication systems are mechanisms able to affect positively the extent of reverse knowledge transfer. However, the study suggests that different communication mechanisms should be emphasized according to the degree of autonomy granted to the foreign subsidiary. Specifically, parent companies' managers can increase the probability of observing reverse knowledge transfer, giving more autonomy to the subsidiaries. However, they should consider that this decentralization is expected to reduce the effectiveness of electronic-based media within the MNE.

The limitations of this study should also be noted. Of course, the context of the study - reverse knowledge transfer within Italian MNEs - was specific; therefore, it imposes limits on the generalizability of our results to other national samples. Nevertheless, the findings suggest that it is worth examining the interdependence among organizational structure dimensions that could be chosen to influence the transfer of knowledge from foreign subsidiaries to their parent companies. As we used perceptual data from a single respondent at the parent company level, albeit with some validity checks at the subsidiary level, we may still have some common-method bias. In this case, the availability of secondary and/or objective data about concepts like subsidiary autonomy, inter-unit communication type, knowledge transfer, would be a valuable source for additional insights. Moreover, we were able to define valid measures for three specific organization structure dimensions: the corporate-subsidiary decentralization, person-based and electronicbased communication systems. Further studies might gain additional understanding by searching for additional organizational controls. Research in information systems, for example, considers electronic communities of practice an important mechanism for transferring and sharing knowledge. Finally, this study analyzed reverse knowledge transfer at the dyadic level. However, a more comprehensive understanding of the hypothesized relationships could be gained by analyzing all the possible knowledge transfer processes between the different entities of an MNE. 


\section{References}

Ai, C., E.C. Norton. 2003. Interaction terms in logit and probit models. Econom. Lett. 80 123-129.

Alavi, M., D.E. Leidner. 2001. Knowledge management and knowledge management systems: conceptual foundations and research issues. MIS Quart. 25(1) 107-136.

Almeida, P., A. Phene, R.M. Grant. 2003. Innovation and knowledge management: scanning, sourcing, and integration. M. Easterby-Smith, M.A. Lyles, eds. Handbook of organizational learning and knowledge management. Blackwell Publishing Ltd, Padstow, Cornwall, UK, 356-371.

Almeida, P., J. Song, R.M. Grant. 2002. Are firms superior to alliances and markets? An empirical test of cross-border knowledge building. Organ. Sci. 13(2) 147-161.

Amabile, T. 1997. Motivating creativity in organizations: on doing what you love and loving what you do. California Management Rev. 40(1) 39-57.

Ambos, B., W.D. Reitsperger. 2004. Offshore center of excellence: social control and success. Management Internat. Rev. 44(2 (Special Issue)) 51-65.

Ambos, B., B.B. Schlegelmilch. 2007. Innovation and control in the multinational firm: a comparison of political and contingency approaches. Strategic Management J. 28 473-486.

Ambos, T.C., B. Ambos, B.B. Schlegelmilch. 2006. Learning from foreign subsidiaries: an empirical investigation of headquarters' benefit from reverse knowledge transfers. Internat. Bus. Rev. 15(3) 294-312.

Andersen, T.J., N.J. Foss. 2005. Strategic opportunity and economic performance in multinational enterprises: The role and effects of information and communication technology. J. of Internat. Management 11 293-310.

Andersson, U., M. Forsgren, U. Holm. 2002. The strategic impact of external networks: subsidiary performance and competence development in the multinational corporation. Strategic Management J. 23 979-996.

Argote, L., P. Ingram. 2000. Knowledge transfer: a basis for competitive advantage in firms. Organ. Behav. and Human Decision Processes 82(1) 150-169. 
Asakawa, K. 1996. External-internal linkages and overseas autonomy-control tension: the management dilemma of the Japanese R\&D in Europe. IEEE Transactions on Engrg. Management 42(1) 24-32.

Asakawa, K. 2001. Organizational tension in international R\&D management: the case of Japanese firms. Res. Policy 30 735-757.

Bartlett, C.A., S. Ghoshal. 1989. Managing across borders: the transnational solution. Harvard Business School Press, Boston.

Birkinshaw, J., N. Hood. 1998. Multinational subsidiary evolution: Capability and charter change in foreign-owned subsidiary companies. Acad. of Management Rev. 23(4) 773-795.

Birkinshaw, J., N. Hood, S. Jonsson. 1998. Building firm-specific advantages in multinational corporations: the role of subsidiary initiative. Strategic Management J. 9 221-241.

Birkinshaw, J., R. Nobel, J. Ridderstrale. 2002. Knowledge as a contingency variable: Do the characteristics of knowledge predict organization structure? Organ. Sci. 13(3) 274-289.

Björkman, I., W. Barner-Rasmussen, L. Li. 2004. Managing knowledge transfer in MNCs: the impact of headquarters control mechanisms. J. of Internat. Bus. Stud. 35 443-455.

Bock, G.-W., R.W. Zmud, Y.-G. Kim. 2005. Behavioral intention formation in knowledge sharing: examining the roles of extrinsic motivators, social-psychological forces, and organizational climate MIS Quart. 29(1) 87-111.

Bresman, H., J. Birkinshaw, R. Nobel. 1999. Knowledge transfer in international acquisitions. J. of Internat. Bus. Stud. 30 439-462.

Brett, J.F., W.L. Cron, J.W.J. Slocum. 1995. Economic dependency on work: a moderator of the relationship between organizational commitment and performance. Acad. of Management J. 38(1) 261-271.

Brockhoff, K.K., B. Schmaul. 1996. Organization, autonomy, and success of internationally dispersed R\&D facilities. IEEE Transactions on Engrg. Management 43(1) 33-40. 
Brusoni, S., A. Prencipe, K.L.R. Pavitt. 2001. Knowledge Specialization, Organizational Coupling, and the Boundaries of the Firm: Why Do Firms Know More Than They Make? Admin. Sci. Quart. 46(4) $597-621$.

Cabrera, A., W.C. Collins, J.F. Salgado. 2006. Determinants of individual engagement in knowledge sharing. Internat. J. of Human Resource Management 17 245-264.

Cantwell, J.A. 1987. The reorganisation of European industries after integration: selected evidence on the role of transnational enterprise activities. J. of Common Market Stud. 26(2) 127-151.

Cantwell, J.A. 1995. The globalisation of technology: what remains of the product cycle model? Cambridge J. of Econom. 19 155-174.

Cantwell, J.A., R. Mudambi. 2005. MNE competence-creating subsidiary mandates. Strategic Management J. 26(12) 1109-1128.

Chini, T.C. 2004. Effective knowledge transfer in multinational corporations. Palgrave Macmillan, New York.

Daft, R.L., R.H. Lengel. 1986. Organizational information requirements, media richness and structural design. Management Sci. 32(5) 554-571.

DeSanctis, G., J. Fulk. 1999. Shaping organization form: Communication, connection, and community. SAGE Publications, Inc., Newbury Park, CA.

Downey, K.H., D. Hellriegel, J.W.J. Slocum. 1975. Environmental Uncertainty: The Construct and Its Application. Admin. Sci. Quart. 20(4) 613-629.

Egelhoff, W.G. 1988. Organizing the multinational enterprise: an information-processing perspective. Ballinger, Cambridge, MA.

Forsgren, M., J. Johanson, D. Sharma. 2000. Development of MNC centres of excellence. U. Holm, T. Pedersen, eds. The emergence and impact of MNC centres of excellence. MacMillan, Basingstoke, 45-67.

Foss, N.J., T. Pedersen. 2002. Transferring knowledge in MNCs: the role of sources of subsidiary knowledge and organization context. J. of Internat. Management 8 49-67. 
Froot, K.A. 1989. Consistent covariance matrix estimation with cross-sectional dependence and heteroskedasticity in financial data. J. of Financial and Quant. Analysis 24 333-355.

Frost, T. 1998. The geographic sources of innovation in the multinational enterprise: U.S. subsidiaries and host country spillovers 1980-1990. Ph.D Dissertation, Massachusetts Institute of Technology, Boston.

Frost, T.S., J.M. Birkinshaw, P.C. Ensign. 2002. Centers of excellence in multinational corporations. Strategic Management J. 23(11) 997-1018.

Gammelgaard, J., U. Holm, T. Pedersen. 2004. The dilemmas of MNC subsidiary knowledge transfer. V. Mahnke, T. Pedersen, eds. Knowledge flows, governance and the multinational enterprise Palgrave Macmillan, New York.

Ghoshal, S. 1986. The innovative multinational: a differentiated network of organizational roles and management processes, Harward Business School.

Ghoshal, S., H. Korine, G. Szulanski. 1994. Interunit communication in multinational corporations. Management Sci. 40(1) 96-110.

Ghoshal, S., N. Nohria. 1989. Internal differentiation within the multinational corporation. Strategic Management J. 10 323-337.

Goodhue, D.L., J.A. Quillard, J.F. Rockart. 1988. Managing the data resource: a contingency perspective. MIS Quart. 12(3) 372-391.

Grant, R.M. 1996. Toward a knowledge-based theory of the firm. Strategic Management J. 17(Winter special issue) 109-122.

Greene, W.H. 2000. Econometric analysis, IV ed. Prentice-Hall, Inc., Upple Saddle River, New Jersey.

Gupta, A.K., V. Govindarajan. 1991. Knowledge flows and the structure of control within multinational corporations. Acad. of Management Rev. 16(4) 768-792.

Gupta, A.K., V. Govindarajan. 2000. Knowledge flows within multinational corporations. Strategic Management J. 21 473-496. 
Haas, M.R., M.T. Hansen. 2005. When using knowledge can hurt performance: the value of organizational capabilities in a management consulting company. Strategic Management J. 26 1-24.

Håkanson, L., R. Nobel. 2000. Technology characteristics and reverse technology transfer. Management Internat. Rev. 40(special issue 1) 29-48.

Håkanson, L., R. Nobel. 2001. Organization characteristics and reverse technology transfer. Management Internat. Rev. 41(special issue 4) 392-420.

Hansen, M.T. 1999. The search-transfer problem: the role of weak ties in sharing knowledge across organisational subunits. Admin. Sci. Quart. 44 82-111.

Hansen, M.T., N. Nohria, T. Tierney. 1999. What's your strategy for managing knowledge? Harvard Bus. Rev. 77(2) 106-116.

Harman, H.H. 1967. Modern factor analysis. University of Chicago Press, Chicago, IL.

Hoetker, G. 2007. The use of logit and probit models in strategic management research: critical issues. Strategic Management J. 28 331-343.

Holm, U., T. Pedersen. 2000. The emergence and impact of MNC centres of excellence. MacMillan, Basingstoke.

Jaeger, A.M., B.R. Baliga. 1985. Control systems and strategic adaptation: lessons from the Japanese experience. Strategic Management J. 6 115-134.

Jarvenpaa, S.L., B. Ives. 1993. Organizing for global competition: the fit of information technology. Decision Sci.s 24(3) 547-580.

Johnson, W.H.A., J.W. Medcof. 2007. Motivating proactive subsidiary innovation: Agent-based theory and socialization models in global R\&D. J. of Internat. Management 13(4) 472-487.

Johnston, S., B. Menguc. 2007. Subsidiary size and the level of subsidiary autonomy in multinational corporations: a quadratic model investigation of Australian subsidiaries. J. of Internat. Bus. Stud. 38 787-801.

Kane, G.C., M. Alavi. 2007. Information technology and organizational learning: an investigation of exploration and expoitation processes. Organ. Sci. 18(5) 796-812. 
Karimi, J., B.R. Konsynski. 1991. Globalization and information management strategies. J. of Management Inform. System 7(4) 7-26.

King, W.R., V. Sethi. 1999. An empirical assessment of the organization of transnational information systems. J. of Management Inform. System 15(4) 7-28.

Kogut, B., H. Singh. 1988. The effect of national culture on the choice of entry mode. J. of Internat. Bus. Stud. 19(3) 411-432.

Kogut, B., U. Zander. 1993. Knowledge of the Firm and the Evolutionary-Theory of the MultinationalCorporation. J. of Internat. Bus. Stud. 24(4) 625-645.

Lane, P.J., J.E. Salk, M.A. Lyles. 2001. Absorptive capacity, learning, and performance in international joint ventures. Strategic Management J. 22(12) 1139-1161.

Lord, M.D., A.L. Ranft. 2000. Organizational learning about new international markets: exploring the internal transfer of local market knowledge. J. of Internat. Bus. Stud. 31(4) 573-589.

March, J.G. 1991. Exploration and Exploitation in Organizational Learning. Organ. Sci. 2 71-87.

Mariotti, S., M. Mutinelli. 2005. Italia multinazionale 2004. Le partecipazioni italiane all'estero e estere in Italia. Rubbettino Editore, Soveria Mannelli.

Minbaeva, D.B., T. Pedersen, I. Björkman, C. Fey, H. Park. 2003. MNC Knowledge Transfer, Subsidiary Absorptive Capacity, and HRM. J. of Internat. Bus. Stud. 34(6) 586-599.

Mudambi, R. 2002. Knowledge management in multinational firms. J. of Internat. Management 8 1-9.

Mudambi, R., S. Mudambi, P. Navarra. 2007. Global innovation in MNCs: the effects of subsidiary selfdetermination and teamwork. J. of Product Innovation Management 24 442-455.

Nahapiet, J., S. Ghoshal. 1998. Social capital, intellectual capital, and the organizational advantage. Acad. of Management Rev. 23 242-266.

Neter, J., W. Wasserman, M. Kutner. 1990. Applied linear statistical models (3rd edn.). Irwin, Homewood, IL. 
Niederman, F. 2005. International business and MIS approaches to multinational organizational research: the cases of knowledge transfer and IT workforce outsourcing. J. of Internat. Management 11 187200.

Nobel, R., J. Birkinshaw. 1998. Innovation in multinational corporations: control and communication patterns in international R\&D operations. Strategic Management J. 19 479-496.

Nohria, N., S. Ghoshal. 1994. Differentiated fit and shared values: alternatives for managing headquarterssubsidiary relations. Strategic Management J. 15(6) 491-502.

Norton, E.C., H. Wang, C. Ai. 2004. Computing interaction effects and standard errors in logit and probit models. The Stata J. 4(2) 154-167.

Nunnally, J.C. 1967. Psychometric Theory. McGraw-Hill, New York, NY.

O’Donnell, S.W. 2000. Managing foreign subsidiaries: agents of headquarters, or an interdependent network? Strategic Management J. 21(5) 525-548.

Osterloh, M., B.S. Frey. 2000. Motivation, Knowledge Transfer, and Organizational Forms. Organ. Sci. 11(5) 538-550.

Paterson, S.L., D.M. Brock. 2002. The development of subsidiary-management research: review and theoretical analysis. Internat. Bus. Rev. 11 139-163.

Pavitt, K.L.R. 1984. Sectoral patterns of technical change: towards a taxonomy and a theory. Res. Policy 13(6) 343-373.

Pearce, R.D. 1999. The evolution of technology in multinational enterprises: the role of creative subsidiaries. Internat. Bus. Rev. 8 125-148.

Pedersen, T., B. Petersen, D.D. Sharma. 2003. Knowledge transfer performance of multinational companies. Management Internat. Rev. 43(3) 69-90.

Persaud, A. 2005. Enhancing synergistic innovative capability in multinational corporations: An empirical investigation. The J. of Product Innovation Management 22 412-429.

Podsakoff, P.M., D.W. Organ. 1986. Self-reports in organizational research: problems and prospects. J. of Management 12(4) 531-544. 
Rao, M.T., C.V. Brown, W.C. Perkins. 2007. Host country resource availability and information system control mechanisms in multinational corporations: an empirical test of resource dependence theory. J. of Management Inform. System 23(4) 11-28.

Rosenkopf, L., P. Almeida. 2003. Overcoming local search through alliances and mobility. Management Sci. 49(6) 751-766.

Sambharya, R.B., A. Kumaraswamy, S. Banerjee. 2005. Information technologies and the future of the multinational enterprise. J. of Internat. Management 11 143-161.

Schoonhoven, C.B. 1981. Problems with contingency theory: Testing assumptions hidden within the language of contingency "theory". Admin. Sci. Quart. 26(3) 349-377.

Schulz, M. 2001. The uncertain relevance of newness: organizational learning and knowledge flows. Acad. of Management J. 44(4) 661-681.

Schulz, M., L.A. Jobe. 2001. Codification and tacitness as knowledge management strategies. An empirical exploration. The J. of High Tech. Management Res. 12 139-165.

Simonin, B.L. 1999. Transfer of marketing know-how in international strategic alliances: An empirical investigation of the role and antecedents of knowledge ambiguity. J. of Internat. Bus. Stud. 30(3) 463-490.

Singh, J. 2005. Collaborative networks as determinants of knowledge diffusion patterns. Management Sci. 51(5) 756-770.

Szulanski, G. 1996. Exploring internal stickiness: impediments to the transfer of best practice within the firm. Strategic Management J. 17 27-43.

Taggart, J., N. Hood. 1999. Determinants of autonomy in multinational corporation subsidiaries. European Management J. 17(2) 226-236.

Tsai, W. 2001. Knowledge transfer in interorganizational networks: effects of network position and absorptive capacity on business unit innovation and performance. Acad. of Management J. 44(5) 996-1004. 
Tsai, W. 2002. Social structure of "coopetition" within a multiunit organization: coordination, competition, and intraorganizational knowledge sharing. Organ. Sci. 13(2) 179-190.

Tsai, W., S. Ghoshal. 1998. Social capital and value creation: the role of intrafirm networks. Acad. of Management J. 41(4) 462-476.

Weiss, L.M. 1998. Collection and Connection: Rationalized and Embedded Knowledge in KnowledgeIntensive Organizations. , Graduate School of Arts and Sciences, Harvard University, Cambridge, MA.

Weiss, L.M., M.M. Capozzi, L. Prusak. 2004. Learning from the internet giants. MIT Sloan Management Rev. 45(4) 79-84.

Williams, R. 2000. A note on robust variance estimation for cluster-correlated data. Biometrics 56 645646.

Young, S., A.T. Tavares. 2004. Centralization and autonomy: back to the future. Internat. Bus. Rev. 13 215-237.

Zack, M. 1999. Developing a knowledge strategy. California Management Rev. 41 125-145.

Zhou, C. 2002. Transnational flows of knowledge in multinational corporations: R\&D co-practice as an integrating force, The University of Western Ontario, Faculty of Graduate Studies, London, Ontario.

Zollo, M., S.G. Winter. 2002. Deliberate learning and the evolution of dynamic capabilities. Organ. Sci. 13(3) 339-351. 


\section{Figures and Tables}

Figure 1 - The size effect of the interactions between subsidiary autonomy and person- and electronicbased communication systems

(a) Subsidiary autonomy $\times$ person-based mech.

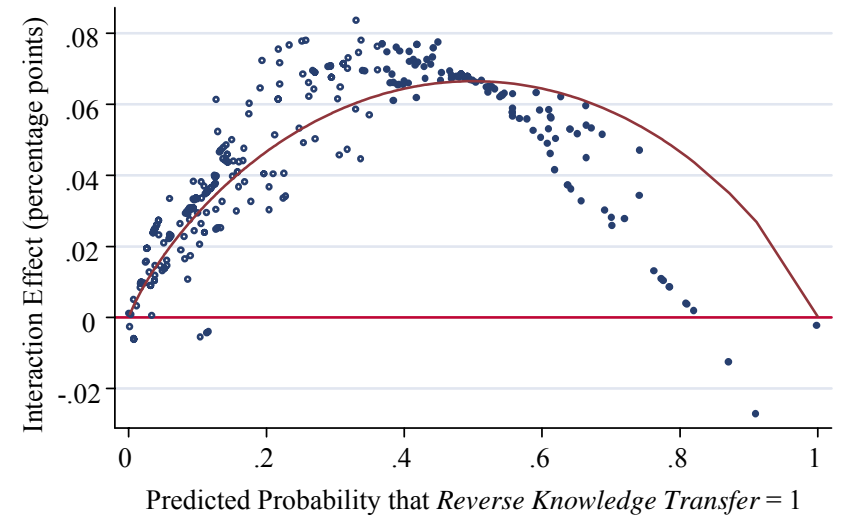

(b) Subsidiary autonomy $\times$ electronic-based mech.

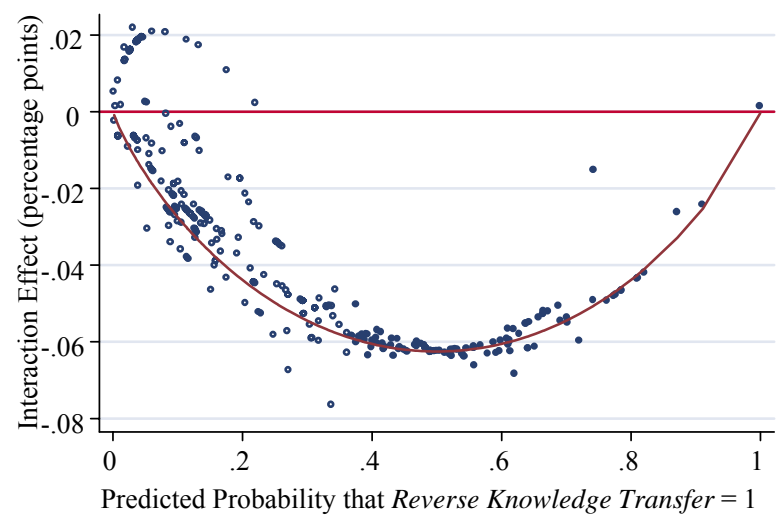

- Correct interaction effect - Incorrect marginal effect

Figure 2 - The significance of the interactions between subsidiary autonomy and person- and electronicbased communication

(a) Subsidiary autonomy $\times$ person-based mech.

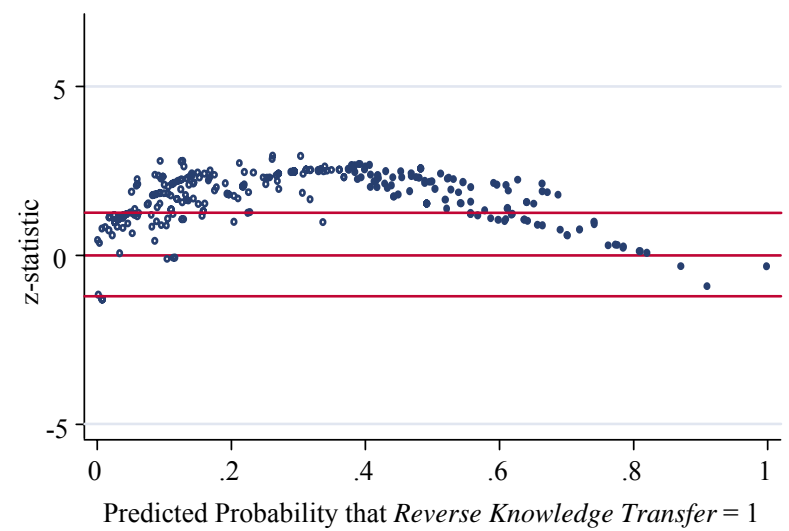

(b) Subsidiary autonomy $\times$ electronic-based mech.

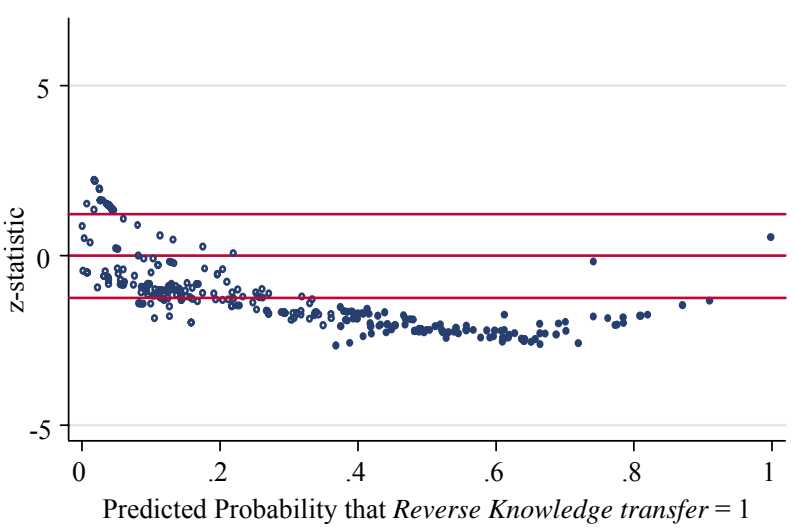

The two horizontal lines represent the z-statistic at \pm 1.64 . All the observations above +1.64 and below -1.64 are significant at least at $\mathrm{p}<0.1$. 
Table 1 - Sample's representativeness

\begin{tabular}{lr|c|c|c|c}
\hline & & Sample frame & Non Respondent & Respondent & $\chi^{2}$ test \\
\hline Industry & & & & \\
& & & & 38 & $0.0008^{* * *}$ \\
\hline Size & & & & \\
& & & & 18 & 0.1624 \\
& $50-249$ & 98 & 66 & 15 & 0.2325 \\
& $250-499$ & 81 & 102 & 43 & $0.0225^{* *}$ \\
$500-5000$ & 145 & 26 & 8 & 0.9924 \\
\hline
\end{tabular}

a 249 MNEs belong to the low-tech sector of which 203 were non respondent.

$* \mathrm{p}<.10 ; * * \mathrm{p}<.05 ; * * * \mathrm{p}<.01$

Table 2 - Validity response tests

\begin{tabular}{lccc}
\hline & Observations $^{\mathrm{a}}$ & Kruskal-Wallis test & P_value \\
\hline $\begin{array}{l}\text { Dependent variable } \\
\quad \text { Degree of reverse knowledge transfer }\end{array}$ & 62 & 1.250 & 0.264 \\
Independent variables & & & \\
$\quad$ Teamwork & 59 & 1.988 & 0.159 \\
$\quad$ Temporary transfer of managers & 55 & 26.988 & $0.000^{* * *}$ \\
$\quad$ Temporary transfer of professionals & 55 & 23.554 & $0.000^{* * *}$ \\
$\quad$ Exchange of blueprints, db, etc. & 57 & 0.015 & 0.904 \\
$\quad$ Internet tools & 56 & 1.621 & 0.203 \\
\hline
\end{tabular}

${ }^{a}$ Number of parent company-foreign subsidiary dyads available.

${ }^{\mathrm{b}}$ Rejecting the null hypothesis means that the two distributions - the answers from the parent companies and the answers from the subsidiaries - are different.

$* \mathrm{p}<.10 ; * * \mathrm{p}<.05 ; * * * \mathrm{p}<.01$

Table 3 - Descriptive statistics

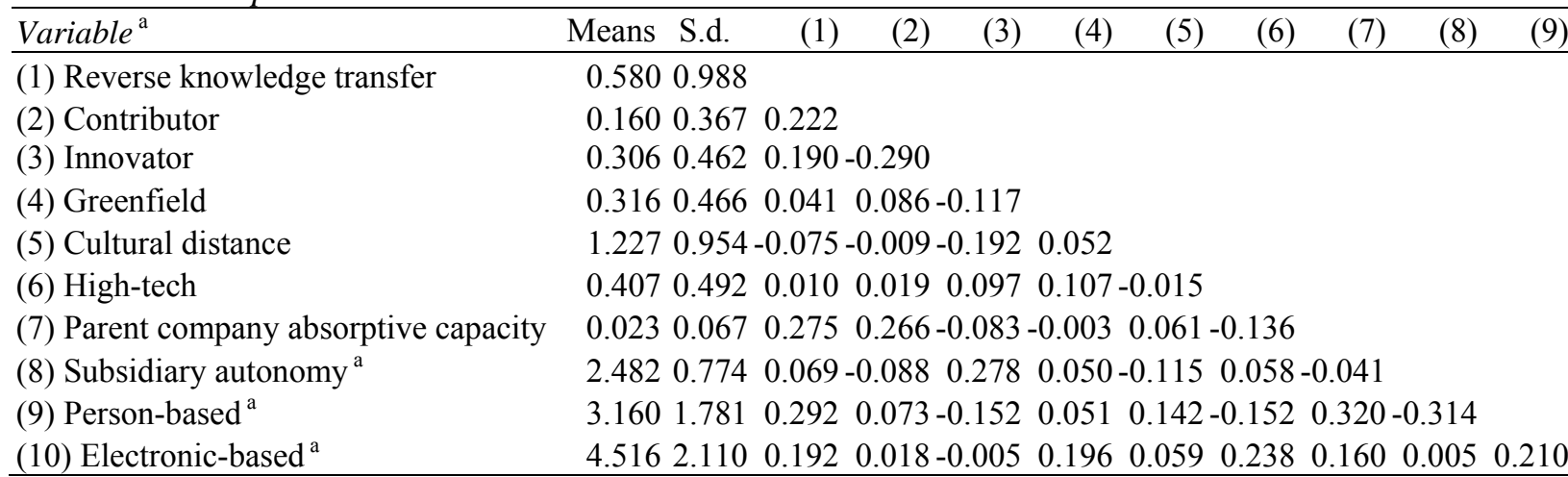

${ }^{\mathrm{a}}$ The variable is standardized. The table lists the means, standard deviations, and correlations of these variables prior to the standardization. 
Table 4 - Results of the ordered probit regressions for reverse knowledge transfer

\begin{tabular}{|c|c|c|c|c|c|c|}
\hline & \multicolumn{2}{|c|}{ Model 1} & \multicolumn{2}{|r|}{ Model 2} & \multicolumn{2}{|c|}{ Model 3} \\
\hline Contributor & 0.821 & $(0.367)^{* *}$ & 1.101 & $(0.389)^{* * *}$ & 1.107 & $(0.379) * * *$ \\
\hline Innovator & 0.847 & $(0.235) * * *$ & 0.991 & $(0.213)^{* * *}$ & 0.894 & $(0.231)^{* * *}$ \\
\hline Greenfield & 0.243 & $(0.289)$ & 0.061 & $(0.205)$ & 0.028 & $(0.207)$ \\
\hline Cultural distance & -0.025 & $(0.110)$ & -0.116 & $(0.089)$ & -0.115 & $(0.090)$ \\
\hline High-tech & -0.129 & $(0.245)$ & -0.175 & $(0.247)$ & -0.175 & $(0.243)$ \\
\hline Parent company absorptive capacity & 3.920 & $(2.206)^{*}$ & 1.555 & (2.087) & 1.428 & (2.022) \\
\hline Subsidiary autonomy & & & 0.184 & $(0.140)$ & 0.320 & $(0.156)^{* *}$ \\
\hline Person-based & & & 0.242 & $(0.086)^{* * *}$ & 0.248 & $(0.080) * * *$ \\
\hline Electronic-based & & & 0.121 & $(0.065)^{*}$ & 0.128 & $(0.063)^{* *}$ \\
\hline Person-based $\times$ Subsidiary autonomy & & & & & 0.198 & $(0.079) * *$ \\
\hline Electronic-based $\times$ Subsidiary autonomy & & & & & -0.176 & $(0.066)^{* * *}$ \\
\hline Log-pseudolikelihood & & -263.88 & & -242.88 & & -235.58 \\
\hline Wald $\chi^{2}$ & & $20.64 * * *$ & & $45.10 * * *$ & & $62.11 * * *$ \\
\hline McFadden's Adjusted Pseudo- $\mathrm{R}^{2}$ & & 0.087 & & 0.156 & & 0.182 \\
\hline
\end{tabular}

In brackets, robust standard errors corrected for heteroscedasticity and cluster-correlated data.

$* \mathrm{p}<.10 ; * * \mathrm{p}<.05 ; * * * \mathrm{p}<.01$ (two-tailed tests applied).

Table 5 - Marginal effects of independent variables on reverse knowledge transfer (RKT)

\begin{tabular}{|c|c|c|c|c|}
\hline Variable $^{\mathrm{a}}$ & $\mathrm{RKT}=0$ & $\mathrm{RKT}=1$ & $\mathrm{RKT}=2$ & $\mathrm{RKT}=3$ \\
\hline Contributor & -0.402 & 0.074 & 0.169 & 0.160 \\
\hline Innovator & -0.305 & 0.077 & 0.134 & 0.094 \\
\hline Greenfield & -0.009 & 0.003 & 0.004 & 0.002 \\
\hline Cultural distance & 0.036 & -0.012 & -0.016 & -0.008 \\
\hline High-tech & 0.055 & -0.018 & -0.024 & -0.013 \\
\hline Parent company absorptive capacity & -0.451 & 0.144 & 0.201 & 0.105 \\
\hline Subsidiary autonomy & -0.101 & 0.032 & 0.045 & 0.024 \\
\hline Person-based & -0.078 & 0.025 & 0.035 & 0.018 \\
\hline Electronic-based & -0.040 & 0.013 & 0.018 & 0.009 \\
\hline Person-based $\times$ Subsidiary autonomy & -0.062 & 0.020 & 0.028 & 0.015 \\
\hline Electronic-based $\times$ Subsidiary autonomy & 0.056 & -0.018 & -0.025 & -0.013 \\
\hline
\end{tabular}

${ }^{a}$ Marginal effect for dummy variable is calculated by comparing the probabilities that result when the variable takes its two different values with those that occur with the other variables held at their sample means (see, for details, Greene 2000).

Table 6 - Results of the probit regressions for reverse knowledge transfer

\begin{tabular}{lrlrlrl}
\hline & \multicolumn{3}{c}{ Model 4 } & \multicolumn{2}{c}{ Model 5 } & \multicolumn{2}{c}{ Model 6 } \\
\hline Constant & -0.939 & $(0.245)^{* * *}$ & -0.824 & $(0.240)^{* * *}$ & -0.721 & $(0.252)^{* * *}$ \\
Contributor & 0.694 & $(0.414)^{*}$ & 0.913 & $(0.426)^{* *}$ & 0.904 & $(0.414)^{* *}$ \\
Innovator & 0.782 & $(0.263)^{* * *}$ & 0.931 & $(0.241)^{* * *}$ & 0.819 & $(0.255)^{* * *}$ \\
Greenfield & 0.366 & $(0.341)$ & 0.206 & $(0.251)$ & 0.185 & $(0.255)$ \\
Cultural distance & -0.022 & $(0.142)$ & -0.105 & $(0.108)$ & -0.108 & $(0.109)$ \\
High-tech & -0.319 & $(0.280)$ & -0.426 & $(0.284)$ & -0.445 & $(0.283)$ \\
Parent company absorptive capacity & 2.123 & $(1.860)$ & -0.487 & $(1.924)$ & -0.651 & $(1.846)$ \\
Subsidiary autonomy & & & 0.113 & $(0.143)$ & 0.262 & $(0.168)$ \\
Person-based & & & 0.231 & $(0.099)^{* *}$ & 0.238 & $(0.095)^{* *}$ \\
Electronic-based & & & 0.145 & $(0.071)^{* *}$ & 0.143 & $(0.070)^{* *}$ \\
Person-based $\times$ Subsidiary autonomy & & & & & 0.167 & $(0.085)^{*}$ \\
Electronic-based $\times$ Subsidiary autonomy & & & & & -0.157 & $(0.071)^{* *}$ \\
Log-pseudolikelihood & & -171.74 & & -151.92 & & -147.26 \\
Wald $\chi^{2}$ & & $18.15^{* * *}$ & & $34.35^{* * *}$ & & $42.17 * * *$ \\
McFadden's Adjusted Pseudo-R & & & & & & \\
\hline
\end{tabular}

In brackets, robust standard errors corrected for heteroscedasticity and cluster-correlated data.

$* \mathrm{p}<.10 ; * * \mathrm{p}<.05 ; * * * \mathrm{p}<.01$ (two-tailed tests applied). 


\section{SMG - Working Papers \\ www.cbs.dk/smg \\ 2003}

2003-1: Nicolai J. Foss, Kenneth Husted, Snejina Michailova, and Torben Pedersen: Governing Knowledge Processes: Theoretical Foundations and Research Opportunities.

2003-2: Yves Doz, Nicolai J. Foss, Stefanie Lenway, Marjorie Lyles, Silvia Massini, Thomas P. Murtha and Torben Pedersen: Future Frontiers in International Management Research: Innovation, Knowledge Creation, and Change in Multinational Companies.

2003-3: Snejina Michailova and Kate Hutchings: The Impact of In-Groups and OutGroups on Knowledge Sharing in Russia and China CKG Working Paper.

2003-4: Nicolai J. Foss and Torben Pedersen: The MNC as a Knowledge Structure: The Roles of Knowledge Sources and Organizational Instruments in MNC Knowledge Management CKG Working Paper.

2003-5: Kirsten Foss, Nicolai J. Foss and Xosé H. Vázquez-Vicente: “Tying the Manager’s Hands": How Firms Can Make Credible Commitments That Make Opportunistic Managerial Intervention Less Likely CKG Working Paper.

2003-6: Marjorie Lyles, Torben Pedersen and Bent Petersen: Knowledge Gaps: The Case of Knowledge about Foreign Entry.

2003-7: Kirsten Foss and Nicolai J. Foss: The Limits to Designed Orders: Authority under "Distributed Knowledge" CKG Working Paper.

2003-8: Jens Gammelgaard and Torben Pedersen: Internal versus External Knowledge Sourcing of Subsidiaries - An Organizational Trade-Off.

2003-9: Kate Hutchings and Snejina Michailova: Facilitating Knowledge Sharing in Russian and Chinese Subsidiaries: The Importance of Groups and Personal Networks Accepted for publication in Journal of Knowledge Management.

2003-10: Volker Mahnke, Torben Pedersen and Markus Verzin: The Impact of Knowledge Management on MNC Subsidiary Performance: the Role of Absorptive Capacity CKG Working Paper.

2003-11: Tomas Hellström and Kenneth Husted: Mapping Knowledge and Intellectual Capital in Academic Environments: A Focus Group Study Accepted for publication in Journal of Intellectual Capital CKG Working Paper.

2003-12: Nicolai J Foss: Cognition and Motivation in the Theory of the Firm: Interaction or "Never the Twain Shall Meet"? Accepted for publication in Journal des Economistes et des Etudes Humaines CKG Working Paper.

2003-13: Dana Minbaeva and Snejina Michailova: Knowledge Transfer and Expatriation Practices in MNCs: The Role of Disseminative Capacity.

2003-14: Christian Vintergaard and Kenneth Husted: Enhancing Selective Capacity Through Venture Bases. 


\section{4}

2004-1: Nicolai J. Foss: Knowledge and Organization in the Theory of the Multinational Corporation: Some Foundational Issues

2004-2: Dana B. Minbaeva: HRM Practices and MNC Knowledge Transfer

2004-3: Bo Bernhard Nielsen and Snejina Michailova: Toward a Phase-Model of Global Knowledge Management Systems in Multinational Corporations

2004-4: Kirsten Foss \& Nicolai J Foss: The Next Step in the Evolution of the RBV: Integration with Transaction Cost Economics

2004-5: Teppo Felin \& Nicolai J. Foss: Methodological Individualism and the Organizational Capabilities Approach

2004-6: Jens Gammelgaard, Kenneth Husted, Snejina Michailova: Knowledge-sharing Behavior and Post-acquisition Integration Failure

2004-7: Jens Gammelgaard: Multinational Exploration of Acquired R\&D Activities

2004-8: Christoph Dörrenbächer \& Jens Gammelgaard: Subsidiary Upgrading? Strategic Inertia in the Development of German-owned Subsidiaries in Hungary

2004-9: Kirsten Foss \& Nicolai J. Foss: Resources and Transaction Costs: How the Economics of Property Rights Furthers the Resource-based View

2004-10: Jens Gammelgaard \& Thomas Ritter: The Knowledge Retrieval Matrix: Codification and Personification as Separate Strategies

2004-11: Nicolai J. Foss \& Peter G. Klein: Entrepreneurship and the Economic Theory of the Firm: Any Gains from Trade?

2004-12: Akshey Gupta \& Snejina Michailova: Knowledge Sharing in Knowledge-Intensive Firms: Opportunities and Limitations of Knowledge Codification

2004-13: Snejina Michailova \& Kate Hutchings: Knowledge Sharing and National Culture: A Comparison Between China and Russia

\section{5}

2005-1: Keld Laursen \& Ammon Salter: My Precious - The Role of Appropriability Strategies in Shaping Innovative Performance

2005-2: Nicolai J. Foss \& Peter G. Klein: The Theory of the Firm and Its Critics: A Stocktaking and Assessment

2005-3: Lars Bo Jeppesen \& Lars Frederiksen: Why Firm-Established User Communities Work for Innovation: The Personal Attributes of Innovative Users in the Case of Computer-Controlled Music

2005-4: Dana B. Minbaeva: Negative Impact of HRM Complementarity on Knowledge Transfer in MNCs

2005-5: Kirsten Foss, Nicolai J. Foss, Peter G. Klein \& Sandra K. Klein: Austrian Capital 
Theory and the Link Between Entrepreneurship and the Theory of the Firm

2005-1: Nicolai J. Foss: The Knowledge Governance Approach

2005-2: Torben J. Andersen: Capital Structure, Environmental Dynamism, Innovation Strategy, and Strategic Risk Management

2005-3: Torben J. Andersen: A Strategic Risk Management Framework for Multinational Enterprise

2005-4: Peter Holdt Christensen: Facilitating Knowledge Sharing: A Conceptual Framework

2005-5 Kirsten Foss \& Nicolai J. Foss: Hands Off! How Organizational Design Can Make Delegation Credible

2005-6 Marjorie A. Lyles, Torben Pedersen \& Bent Petersen: Closing the Knowledge Gap in Foreign Markets - A Learning Perspective

2005-7 Christian Geisler Asmussen, Torben Pedersen \& Bent Petersen: How do we Capture "Global Specialization" when Measuring Firms' Degree of internationalization?

2005-8 Kirsten Foss \& Nicolai J. Foss: Simon on Problem-Solving: Implications for New Organizational Forms

2005-9 Birgitte Grøgaard, Carmine Gioia \& Gabriel R.G. Benito: An Empirical Investigation of the Role of Industry Factors in the Internationalization Patterns of Firms

2005-10 Torben J. Andersen: The Performance and Risk Management Implications of Multinationality: An Industry Perspective

2005-11 Nicolai J. Foss: The Scientific Progress in Strategic Management: The case of the Resource-based view

2005-12 Koen H. Heimeriks: Alliance Capability as a Mediator Between Experience and Alliance Performance: An Empirical Investigation Into the Alliance Capability Development Process

2005-13 Koen H. Heimeriks, Geert Duysters \& Wim Vanhaverbeke: Developing Alliance Capabilities: An Empirical Study

2005-14 JC Spender: Management, Rational or Creative? A Knowledge-Based Discussion

\section{6}

2006-1: Nicolai J. Foss \& Peter G. Klein: The Emergence of the Modern Theory of the Firm

2006-2: Teppo Felin \& Nicolai J. Foss: Individuals and Organizations: Thoughts on a Micro-Foundations Project for Strategic Management and Organizational Analysis

2006-3: Volker Mahnke, Torben Pedersen \& Markus Venzin: Does Knowledge Sharing 
Pay? An MNC Subsidiary Perspective on Knowledge Outflows

2006-4: Torben Pedersen: Determining Factors of Subsidiary Development

2006-5 Ibuki Ishikawa: The Source of Competitive Advantage and Entrepreneurial Judgment in the RBV: Insights from the Austrian School Perspective

2006-6 Nicolai J. Foss \& Ibuki Ishikawa: Towards a Dynamic Resource-Based View: Insights from Austrian Capital and Entrepreneurship Theory

2006-7 Kirsten Foss \& Nicolai J. Foss: Entrepreneurship, Transaction Costs, and Resource Attributes

2006-8 Kirsten Foss, Nicolai J. Foss \& Peter G. Klein: Original and Derived Judgement: An Entrepreneurial Theory of Economic Organization

2006-9 Mia Reinholt: No More Polarization, Please! Towards a More Nuanced Perspective on Motivation in Organizations

2006-10 Angelika Lindstrand, Sara Melen \& Emilia Rovira: Turning social capital into business? A study of Swedish biotech firms' international expansion

2006-11 Christian Geisler Asmussen, Torben Pedersen \& Charles Dhanaraj: Evolution of Subsidiary Competences: Extending the Diamond Network Model

2006-12 John Holt, William R. Purcell, Sidney J. Gray \& Torben Pedersen: Decision Factors Influencing MNEs Regional Headquarters Location Selection Strategies

2006-13 Peter Maskell, Torben Pedersen, Bent Petersen \& Jens Dick-Nielsen: Learning Paths to Offshore Outsourcing - From Cost Reduction to Knowledge Seeking

2006-14 Christian Geisler Asmussen: Local, Regional or Global? Quantifying MNC Geographic Scope

2006-15 Christian Bjørnskov \& Nicolai J. Foss: Economic Freedom and Entrepreneurial Activity: Some Cross-Country Evidence

2006-16 Nicolai J. Foss \& Giampaolo Garzarelli: Institutions as Knowledge Capital: Ludwig M. Lachmann's Interpretative Institutionalism

2006-17 Koen H. Heimriks \& Jeffrey J. Reuer: How to Build Alliance Capabilities

2006-18 Nicolai J. Foss, Peter G. Klein, Yasemin Y. Kor \& Joseph T. Mahoney: Entrepreneurship, Subjectivism, and the Resource - Based View: Towards a New Synthesis

2006-19 Steven Globerman \& Bo B. Nielsen: Equity Versus Non-Equity International Strategic Alliances: The Role of Host Country Governance

\section{7}

2007-1 Peter Abell, Teppo Felin \& Nicolai J. Foss: Building Micro-Foundations for the Routines, Capabilities, and Performance Links 
2007-2 Michael W. Hansen, Torben Pedersen \& Bent Petersen: MNC Strategies and Linkage Effects in Developing Countries

2007-3 Niron Hashai, Christian G. Asmussen, Gabriel R.G. Benito \& Bent Petersen: Predicting the Diversity of Foreign Entry Modes

2007-4 Peter D. Ørberg Jensen \& Torben Pedersen: Whether and What to Offshore?

2007-5 Ram Mudambi \& Torben Pedersen: Agency Theory and Resource Dependency Theory: Complementary Explanations for Subsidiary Power in Multinational Corporations

2007-6 Nicolai J. Foss: Strategic Belief Management

2007-7 Nicolai J. Foss: Theory of Science Perspectives on Strategic Management Research: Debates and a Novel View

2007-8 Dana B. Minbaeva: HRM Practices and Knowledge Transfer in MNCs

2007-9 Nicolai J. Foss: Knowledge Governance in a Dynamic Global Context: The Center for Strategic Management and Globalization at the Copenhagen Business School

2007-10 Paola Gritti \& Nicolai J. Foss: Customer Satisfaction and Competencies: An Econometric Study of an Italian Bank

2007-11 Nicolai J. Foss \& Peter G. Klein: Organizational Governance

2007-12 Torben Juul Andersen \& Bo Berhard Nielsen: The Effective Ambidextrous Organization: A Model of Integrative Strategy Making Processes.

\section{8}

2008-1 Kirsten Foss \& Nicolai J. Foss: Managerial Authority When Knowledge is Distributed: A Knowledge Governance Perspective

2008-2 Nicolai J. Foss: Human Capital and Transaction Cost Economics.

2008-3 Nicolai J. Foss \& Peter G. Klein: Entrepreneurship and Heterogeneous Capital.

2008-4 Nicolai J. Foss \& Peter G. Klein: The Need for an Entrepreneurial Theory of the Firm.

2008-5 Nicolai J. Foss \& Peter G. Klein: Entrepreneurship: From Opportunity Discovery to Judgment.

2008-6 Mie Harder: How do Rewards and Management Styles Influence the Motivation to Share Knowledge?

2008-7 Bent Petersen, Lawrence S. Welch \& Gabriel R.G. Benito: Managing the Internalisation Process - A Theoretical Perspective.

2008-8 Torben Juul Andersen: Multinational Performance and Risk Management Effects: Capital Structure Contingencies. 
2008-9 Bo Bernard Nielsen: Strategic Fit and the Role of Contractual and Procedural Governance in Alliances: A Dynamic Perspective.

2008-10 Line Gry Knudsen \& Bo Bernhard Nielsen: Collaborative Capability in R\&D Alliances: Exploring the Link between Organizational and Individual level Factors.

2008-11 Torben Juul Andersen \& Mahesh P. Joshi: Strategic Orientations of Internationalizing Firms: A Comparative Analysis of Firms Operating in Technology Intensive and Common Goods Industries.

2008-12 Dana Minbaeva: HRM Practices Affecting Extrinsic and Intrinsic Motivation of Knowledge Receivers and their Effect on Intra-MNC Knowledge Transfer.

2008-13 Steen E. Navrbjerg \& Dana Minbaeva: HRM and IR in Multinational Corporations: Uneasy Bedfellows?

2008-14 Kirsten Foss \& Nicolai J. Foss: Hayekian Knowledge Problems in Organizational Theory.

2008-15 Torben Juul Andersen: Multinational Performance Relationships and Industry Context.

2008-16 Larissa Rabbiosi: The Impact of Subsidiary Autonomy on MNE Knowledge Transfer: Resolving the Debate. 